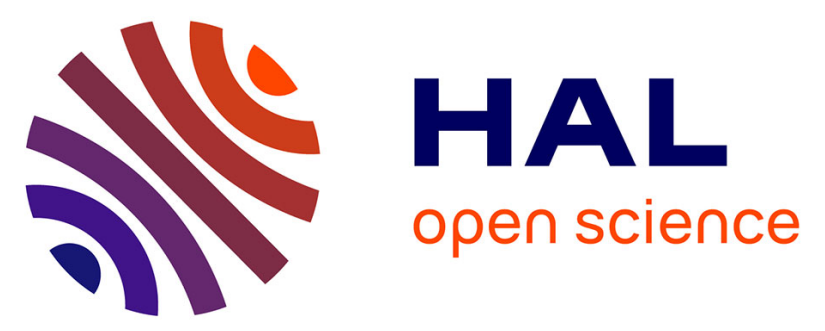

\title{
Polyaniline based composite layers for photovoltaïc applications: Thermal and optical properties investigation
}

Douniazad Mezdour, Jean-François Bardeau, Nicolas Errien, Jean-François Pilard, Mohamed Tabellout

\section{To cite this version:}

Douniazad Mezdour, Jean-François Bardeau, Nicolas Errien, Jean-François Pilard, Mohamed Tabellout. Polyaniline based composite layers for photovoltaïc applications: Thermal and optical properties investigation. THE 9TH INTERNATIONAL CONFERENCE ON STRUCTURAL ANALYSIS OF ADVANCED MATERIALS - ICSAAM 2019, Sep 2019, Ischia, Italy. pp.020002, 10.1063/1.5140275 . hal-03029172

\section{HAL Id: hal-03029172 \\ https://hal.science/hal-03029172}

Submitted on 30 Nov 2020

HAL is a multi-disciplinary open access archive for the deposit and dissemination of scientific research documents, whether they are published or not. The documents may come from teaching and research institutions in France or abroad, or from public or private research centers.
L'archive ouverte pluridisciplinaire HAL, est destinée au dépôt et à la diffusion de documents scientifiques de niveau recherche, publiés ou non, émanant des établissements d'enseignement et de recherche français ou étrangers, des laboratoires publics ou privés. 


\section{Polyaniline based composite layers for photovoltaiic applications: Thermal and optical properties investigation}

Douniazad Mezdour, Jean-François Bardeau, Nicolas Errien, Jean-François Pilard, and Mohamed Tabellout 


\title{
Polyaniline Based Composite Layers for Photovoltaïc Applications: Thermal and Optical Properties Investigation
}

\author{
Douniazad Mezdour ${ }^{1, \text { a) }}$, Jean-François Bardeau ${ }^{2, \text { b) }}$, Nicolas Errien ${ }^{2, c)}$, Jean- \\ François Pilard ${ }^{2, d)}$, Mohamed Tabellout ${ }^{2, e)}$ \\ ${ }^{1}$ Laboratoire d'étude des matériaux, Mohamed Seddik Benyahia University, Ouled Aissa, BP 98, 18000 Jijel, Algéria \\ ${ }^{2}$ Institut des Molécules et Matériaux du Mans, UMR CNRS 6283, Le Mans Université, Avenue Olivier Messiaen \\ 72085, Le Mans cedex 9, France
}

\begin{abstract}
This paper reports on the synthesis and physical properties of conducting composites based on polyaniline and polystyrene. Polyaniline composite powders are synthesized by oxidative polymerization in an acidic medium. Thermal properties are characterized by thermo gravimetric analysis and differential scanning calorimetry. UV-Visible absorption spectroscopy is also used to study the optical properties of the deposited films. The optical gap decreases from $4.6 \mathrm{eV}$ to 2.7 $\mathrm{eV}$ with increasing polyaniline content from 0.5 to 5 wt. $\%$ confirming the improvement of the semi-conductive properties. Due to the absorption properties in near infrared of the thin composite layers they can be promising materials for optoelectronic and photovoltaic applications.
\end{abstract}

Keywords: Polymer; Polyaniline; Polystyrene; Thermal; Optical properties

\section{INTRODUCTION}

Organic electronics has emerged as a new frontier area for flexible printable electronics. Intensive studies have been conducted on conjugated materials due to their relatively rapid photo-induced charge separation and slow charges recombination [1]. Besides brightness and weight features of electroluminescent polymers [2], tuning the emission wavelength is also possible [3]. Due to their ability to emit colours throughout the visible spectrum with high luminous efficiency, organic electroluminescent devices have attracted a growing interest for display applications.

Small molecules or polymers are the main constituting materials of organic light emitting diodes (OLEDs) $[2,4]$. Polymers generally have lower purity than small molecules but can access larger display sizes and full color at much lower costs via solution-based deposition techniques [5]. Among the conjugated conducting polymers, Polyaniline (PANI) has attracted considerable interest as an air-stable conducting polymer for several reasons; monomer is inexpensive and polymerization reaction is simple. It has also unique reversible proton doping, high electrical conductivity and environmental stability [6]. Emeraldine base that is protonated with different acids has been investigated as a photoactive layer in Schottky diodes [7,8] as well as hole injection layer and anode in light emitting diodes (LED). However, PANI is mechanically weak and its processability is poor, degrades before melting, and also limitedly soluble in organic solvents. In order to circumvent these problems, many research groups $[9,10]$ have utilized the approach of synthesizing composites and copolymers. 
Flexible, tough and melt processible PANI could be obtained by keeping its composition less than $16 \%$ in weight (wt \%) of the blend [11]. Several thermoplastic polymers such as polystyrene (PS) [12], polyvinyl chloride (PVC) [13], polyamides (PA) [14], polyvinyl alcohol (PVA) [15] were combined with PANI salt to obtain conductive blends. In this study, an "inert" polymer-polystyrene, was chosen as the matrix polymer to form blends with.

\section{EXPERIMENTAL PART}

Preparation of PS/PANI powders consists in a chemical oxidative polymerization of aniline using ammonium per sulphate (APS) as initiator, in the presence of dodecyl benzene sulphonic acid (DBSA) and polystyrene. The polymerization is carried out for about $24 \mathrm{~h}$ at room temperature. The powder is then filtered, washed and dried in oven (at $60{ }^{\circ} \mathrm{C}$ for 2 days). Different concentrations of PS/PANI composites, $0.1 \%, 0.5 \%, 1 \%, 5 \%$ and $15 \%$ in weight are prepared using the above procedure. Powders were then transformed into films by solution casting.

\section{RESULTS AND DISCUSSION}

\section{Thermal Properties}

The thermo gravimetric profiles of PANI and PS/PANI polymer composite are shown in Fig. 1. Slight modifications of the total weight loss curves are observed for the composites with the increasing PS content (Fig. 1b). The first loss of about $2 \%$ at $250{ }^{\circ} \mathrm{C}$ is related to water removal. The second process lying between $250{ }^{\circ} \mathrm{C}$ and $400{ }^{\circ} \mathrm{C}$ is due to the degradation of doping agent. Finally the last step corresponds to the beginning of degradation of the two polymers chains. Compared to PANI alone (Fig. 1-a), the major loss is delayed until $400{ }^{\circ} \mathrm{C}$ for the composite films which proves that the mixing of PANI in PS improves the thermal stability (about $150^{\circ} \mathrm{C}$ are gained). This feature allows using these materials in hot environment (PV cells). Indeed, temperatures of a PV cell can reach $70{ }^{\circ} \mathrm{C}[16]$ which is far bellow $200^{\circ} \mathrm{C}$ registered for a thermally stable powder.

Differential scanning calorimetry (DSC) measurements of PANI and PS/PANI composites are shown in Fig. 2. No significant change has been noticed in the glass transition of PS/PANI composites according to the PANI fraction compared to the known PS glass transition [17]. It is estimated to be about $110{ }^{\circ} \mathrm{C}$. The second peak observed at $225{ }^{\circ} \mathrm{C}$ is attributed to melting point of polystyrene. Indeed, in the literature the melting point is expected between $240-270{ }^{\circ} \mathrm{C}[18]$.

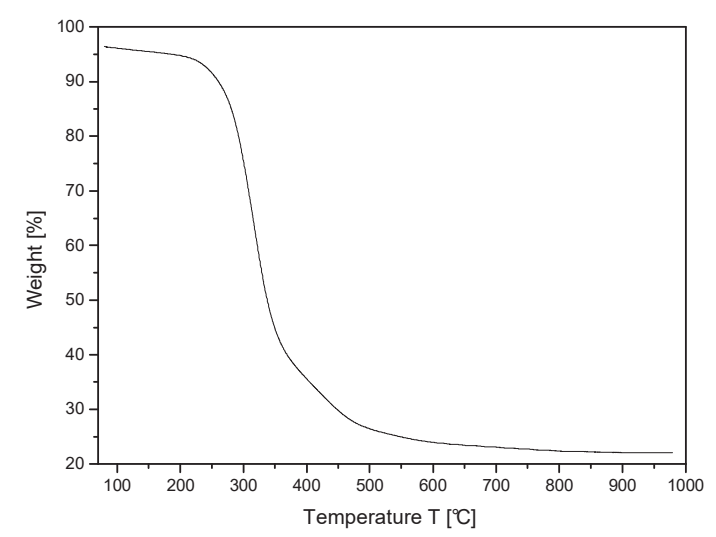

(a)

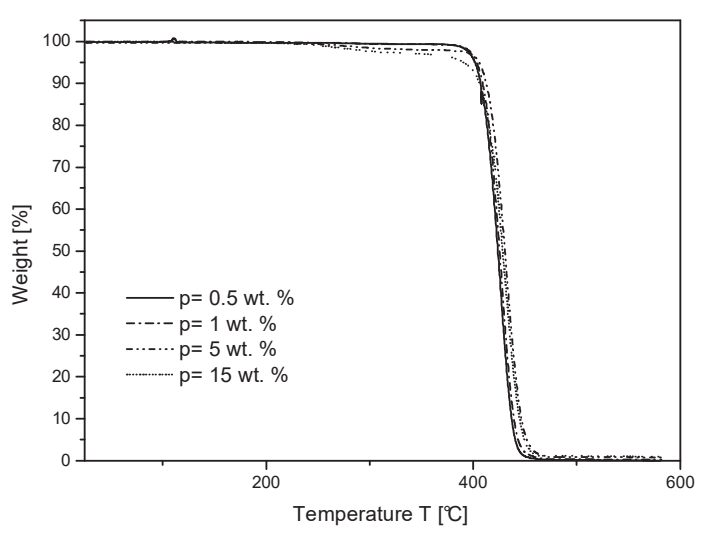

(b)

FIGURE 1. Total weight loss of (a) PANI and (b) PS/PANI polymer composite.

\section{Optical absorption spectroscopy}

Optical properties are deduced from the UV-vis measurements. The UV-vis absorption spectra of PANI-PS composites are shown in Fig. 3. Two small absorption bands are observed in the 300-450 $\mathrm{nm}$ wavelength region 


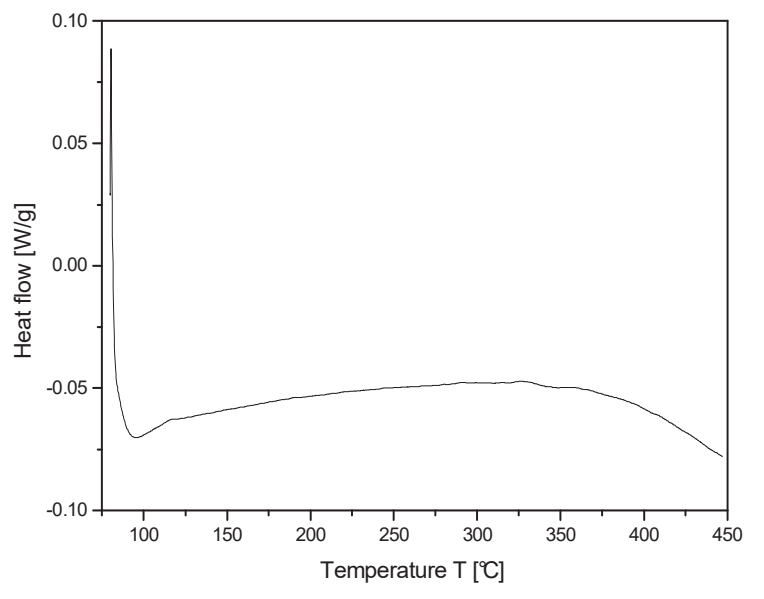

(a)

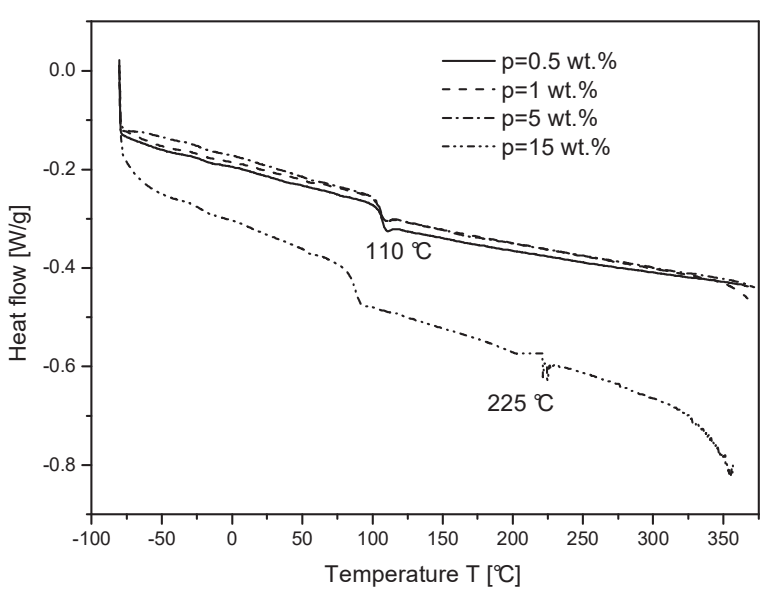

(b)

FIGURE 2. DSC measurements of (a) PANI and (b) PS/PANI polymer composite.

and a broad band centered at $800 \mathrm{~nm}$ and are assigned respectively to the $\pi-\pi^{*}$ transition of the benzenoid rings located at $340 \mathrm{~nm}$, the polaron- $\pi^{*}$ transition at $\sim 440 \mathrm{~nm}$ and polaron- $\pi$ transition due to charge transfer excitations of the quinoid structure around $800 \mathrm{~nm}[19,20]$. This indicates that the in situ synthesized polyaniline have been effectively doped by the protonic acid. It is also observed that most of the absorption peaks appear above the concentration of $0.5 \mathrm{wt} . \%$ and intensify with the increase in PANI concentration indicating an uniform doping ratio. This can be also explained by the fact that films become less transparent and absorb in the near infrared domain corresponding to wavelengths $\lambda_{I R}>700 \mathrm{~nm}$. Indeed films take a light green colour at low concentrations. This colour becomes more darkened at high concentrations.

The absorption peaks are clearly visible in Fig. 4 illustrating the derivative of the absorbance versus energy (eV). For low PANI concentration composites, we notice the presence of a strong absorption band corresponding to the optical gap of the matrix. Indeed for the pure polystyrene, the optical gap is estimated to be of $4.47 \mathrm{eV}$ corresponding to the insulating state of the transparent polystyrene. At 5\% of PANI, no perceptible change is observed for the high gap (except a slight decrease in intensity), but we notice the presence of another absorption energy located at $2.68 \mathrm{eV}$ probably due to the presence of PANI. Indeed, the known band gap energy of PANI lays in the visible region $2.7 \mathrm{eV}$ [21]. Introducing PANI in the polystyrene matrix shifts its gap energy backward visible region and enhances its conductivity while electroluminescence of the composite is enhanced by polystyrene [22] that could be interesting for optoelectronic applications.

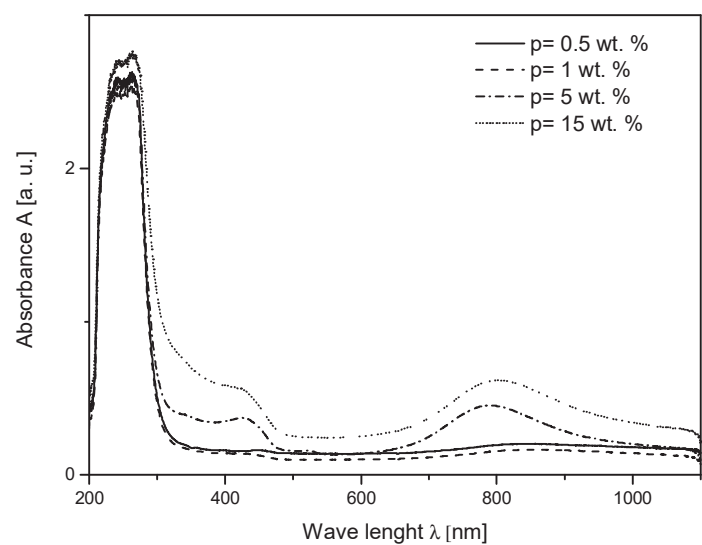

FIGURE 3. UV-vis absorbance of PS films containing different concentrations of PANI.

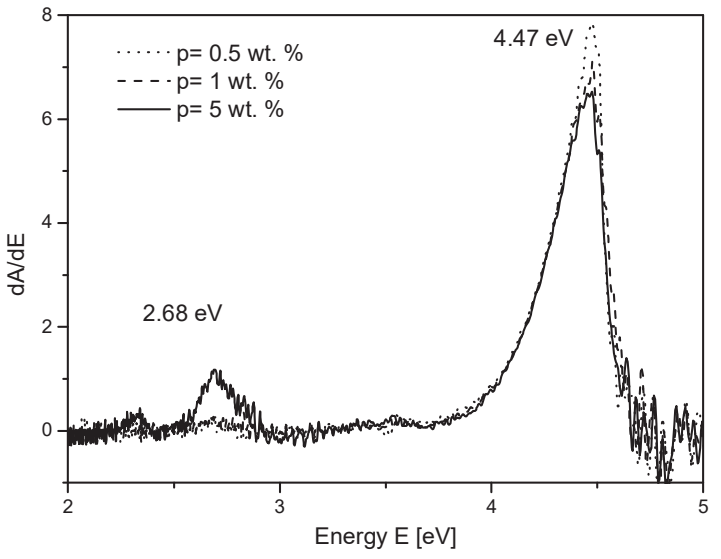

FIGURE 4. Variation of the Absorbance derivative versus the energy for different concentrations $p$ of PANI. 


\section{CONCLUSIONS}

The study of thermal and optical properties of PS/PANI layers with various concentrations of PANI led to the following observations:

Electronic absorption results support the formation of polyaniline salts. The UV-Visible spectra indicate that there is a single broad polaronic band deep in the band gap of the PS/PANI layers. Films absorb in the near infrared region and the optical gap of the PS decreases when incorporating PANI. The composites are thermally stable up to $200{ }^{\circ} \mathrm{C}$ allowing their use in hot environments.

Our results show that such composite may be promising materials for potential application in photovoltaic technology including ease of synthesis, low cost, good thermal stability and good film-forming.

\section{REFERENCES}

1. Y. G. Wang, H. Q Li and Y. Y Xia, Adv. Mater. 18, 2619-2623 (2006).

2. J. H. Burroughes, D. D. C.Bradley, A. R. Brown, R. N. Marks, K. Mackey, R. H. Friend, P. K. Burns and A. B.Holmes,

Nature 347, 539-541 (1990).

3. C. Zhang, D. Braun and A. J Heeger, J. Appl. Phys. 73, 5177-5180 (1993).

4. L. S Hung and C. H. Chen, Mater. Sci. Eng. R. 39, 143-222 (2002).

5. B. de Gans, P. C. Duineveld and U.S. Schubert, Adv. Mater. 16, 203-213 (2004).

6. Y. Cao, P. Smith and A. J. Heeger, Synth. Met. 48, 91-97 (1992).

7. R. W. T. Higgins, N. A. Zaidi and A. P. Monkman, Adv. Funct. Mater. 11, 407-412 (2001).

8. S. -An. Chen and Y. Fang, Synth. Met. 60, 215-222 (1993).

9. M. Zilberman, G. I. Titleman, A. Siegmann, Y. Haba, M. Narkis and D. Alperstein, J. Appl. Polym. Sci. 66, 243-253

(1997).

10. A. L. Schemid, L. M. Lira and S. I. Cordoba de Torresi, Electrochim. Acta 47, 2005-2011 (2002).

11. J. Anand, S. Palaniappan and D. N. Sathyanarayana, Prog. Polym. Sci. 23, 993-1018 (1998).

12. V. Jousseaume, M. Morsli, A. Bonnet and S. Lefrant, J. Appl. Polym. Sci. 67, 1209-1214 (1998).

13. P. Banerjee and B. M. Mandal, Macromolecules 28, 3940-3943 (1995).

14. D. Mezdour, M. Tabellout, S. Sahli and J. -F. Bardeau, ", " in 3rd International Advances in Applied Physics and

Materials Science Congress-2013, AIP Conference Proceedings 1569, edited by A. Y. Oral et al. (American Institute of Physics, Melville, NY, 2013), pp. 319-322.

15. P. S. Rao, S. Subrahmanya and D. N. Sathyanarayana, J. Appl. Polym. Sci. 98, 583-590 (2005).

16. A. Labouret and M. Villoz, Energie solaire photovoltaïque $4^{\text {th }}$ edition (Dunod, Paris, 2009).

17. http://www.atomer.fr/1/1a-Tg-temperature-transition-vitreuse.html (accessed July 14, 2018).

18. http://www.inrs.fr/dms/plastiques/PolymerePlastiques/...polymere.../POLYMERE_PS.pdf (accessed April 26, 2018).

19. S. Sathiyanarayanan, S. S. Azim and G. Venkatachari, Synth. Met. 157, 751-757 (2007).

20. Y. Cao, S. Z. Li, Z. J. Xue and D. Guo, Synth. Met. 16(3), 305-315 (1986).

21. I. D. Sharma, P. K. Saini and V. K. Sharma, Indian J. Eng. Mater. Sci. 20, 145-149 (2013).

22. G. He, Y. Li, J. Liu and Y. Yang, Appl. Phys. Lett. 80(22), 4247-4249 (2002). 